\title{
THE FIRST OUTBREAK OF LACTOCOCCOSIS CAUSED BY LACTOCOCCUS GARVIEAE IN SERBIA
}

\author{
Vladimir Radosavljevic ${ }^{1 *}$, Oliver Radanovic ${ }^{1}$, \\ Nemanja Zdravkovic ${ }^{1}$, Bozidar Savic ${ }^{1}$, Marko Stankovic ${ }^{2}$, \\ Jelena Maksimovic-Zoric ${ }^{1}$, Ljubiša Veljović ${ }^{1}$, Ksenija Nesic ${ }^{1}$ \\ ${ }^{1}$ Institute of Veterinary Medicine of Serbia, Belgrade, Republic of Serbia \\ ${ }^{2}$ Faculty of Agriculture, University of Belgrade, Zemun, Republic of Serbia
}

\section{Abstract}

The outbreak of lactococcosis affecting rainbow trout, weighing 70 $120 \mathrm{~g}$, occurred at a trout aquaculture facility in Central-West Serbia during July, 2018. This outbreak lasted for three weeks, and cumulative mortality attributed to the disease was around $40 \%$. The diseased fish showed erratic swimming, dark discoloration and exophthalmia, with the cumulative mortality of around $40 \%$. A pure Gram-positive cocci isolates were obtained from the eye and kidney samples. Based on colony morphology, phenotypic and biochemical characteristics, the isolated bacterium was presumably identified as Lactococcus garvieae. Using the BBL CRYSTAL GP ID system, the isolate was identified as L. garvieae and the identity of the isolate was confirmed with MALDI-TOF Mass Spectrometry. Blast analysis of $16 \mathrm{~S}$ rRNA sequence of our isolate had a 99.4 to $99.6 \%$ similarity to the L. garvieae strains previously isolated from diseased fish. The antibacterial activity of 15 antimicrobials against $L$. garvieae was evaluated using disc diffusion. In this paper, we report the first case of lactococcosis in rainbow trout in Serbia, isolation and characterization of causative agent, Lactococcus garvieae from diseased rainbow trout.

Key words: Lactococcosis, Lactococcus garvieae, rainbow trout

${ }^{1 \star}$ Corresponding author: vladimiradosavljevic@yahoo.co.uk 


\title{
PRVI SLUČAJ LAKTOKOKOZE IZAZVANE SA LACTOCOCCUS GARVIEAE U SRBIJI
}

\author{
Vladimir Radosavljevićl», Oliver Radanović ${ }^{1}$, \\ Nemanja Zdravkovićn , Bozidar Savic ${ }^{1}$, Marko Stankovićn \\ Jelena Maksimović-Zorić ${ }^{1}$, Ljubiša Veljovićn ${ }^{1}$ Ksenija Nešić ${ }^{1}$ \\ ${ }^{1}$ Naučni institut za veterinarstvo Srbije, Beograd, Republika Srbija \\ ${ }^{2}$ Poljoprivredni fakultet, Univerzitet u Beogradu, Zemun, Republika Srbija
}

\section{Kratak sadržaj}

Pojava laktokokoze u zapatu kalifornijske pastrmke, težine 70 - 120 g, je utvrđena na pastrmskom ribnjaku u zapadnoj Srbiji u julu 2018. godine. Bolest je trajala tri nedelje, a kumulativni mortalitet nastao kao posledica oboljenja je iznosio oko 40\%. Klinička slika se karakterisala promenama u plivanju, tamnom pigmentacijom kože i izraženim egzoftalmusom. Na osnovu morfoloških i biohemijskih karakteristika, izolovana bakterija je identifikovana kao Lactococcus garvieae. Korišćenjem BBL CRYSTAL GP ID sistema, izolat je identifikovan kao L. garvieae, a identitet izolata je potvrđen pomoću MALDI-TOF masene spektrometrije. Analiza 16Sr RNK sekvence našeg izolata pokazala je sličnost od 99,4 do 99,6\% sa sekvencama sojeva $L$. garvieae prethodno izolovanih iz obolelih riba. Antibakterijska aktivnost 15 antimikrobnih lekova protiv L. garvieae procenjena je metodom disk difuzije. U radu je opisan prvi slučaj pojave laktokokoze kalifornijske pastrmke u Srbiji i izolacija i karakterizacija uzročnika bolesti.

Ključne reči: laktokokoza, Lactococcus garvieae, kalifornijska pastrmka

\section{INTRODUCTION}

Lactococcosis is a significant fish disease caused by the Lactococcus garvieae bacteria. It is a systemic hyper-acute infection with the occurrence of widespread haemorrhaging (Austin \& Austin 2016), described for the first time at the end of the 1950s in Japan, where the first cases were diagnosed in rainbow trout (Vendrell et al. 2006). Now, the disease is present in many parts of the world, affecting sea fish and freshwater fish in aquaculture (Meyburgh et al. 2017). Rainbow trout is an important species for aquaculture in Serbia, 
with more than 100 farms in business. Trout farms are mainly concentrated in South-East part of the country. In Europe, the first outbreak of this disease in rainbow trout was reported in Spain in 1989 (Palacios et al., 1993). After that, L. garvieae was isolated in Italy (Reimundo et al. 2011), the UK (Algöet et al. 2009), France (Eyngor et al. 2004), Portugal (Pereira et al. 2004), Greece (Savvidis et al. 2007), Spain (Aguado-Urda et al. 2011), Turkey (Diler et al. 2002) and Bulgaria (Eyngor et al. 2004). Lactococcosis is the single most important risk factor in the European trout industry, with losses approximating $50 \%$ of the total annual production (Eyngor et al., 2004). The impact of lactococcosis is particularly significant as losses often occur when fish reach market size (Ceschia et al. 1998). The disease causes significant losses at temperatures above $15^{\circ} \mathrm{C}$. The oral route is the main route of L. garvieae transmission (Nakai et al. 1999), but the results of a study conducted by Avci et al. (2010) suggest that the gills and eyes are major spots of attachment and the proliferation of L. garvieae during infection period. Infected fish exhibit a variety of clinical signs, such as anorexia, exophthalmia, melanosis, conjunctivitis, erect swimming, severe internal haemorrhage and congestion of blood vessel, peritonitis, abscess of spleen and liver, meningoencephalitis, and bacterial septicemia (Eldaret al.1999, Evans et al.2009, Pereira et al. 2004).

The causative agent, L. garvieae is one of the most important bacterial fish pathogens indifferent freshwater and marine fish species in many countries (Vendrell et al. 2006; Evans et al. 2009, Meyburgh et al. 2017), with the highest economic impact in rainbow trout aquaculture. L. garvieae is a nonmotile, non-sporulating, facultative anaerobic, catalase and cytochrome oxidase negative, Gram-positive coccus. It is a lactic acid bacterium, first isolated from a case of bovine mastitis it the UK (Collins et al. 1983), and later from other animal hosts, such as cows, buffalos, pigs, dolphins, water buffalos, cats and dogs (Aguado-Urda et al. 2013, Tejedor et al. 2011). The bacterium was isolated from rivers and sewage waters, vegetables, meat and dairy products (Aguado-Urda et al. 2013). L. garvieae strains of dairy origin have been found to be free from virulence determinants, such as haemolysins and gelatinase (Fortina et al., 2007), suggesting that L. garvieae dairy strains are unrelated to the pathogenic ones (Foschino et al., 2008). Also, L. garvieae was involved in an increasing number of human clinical cases including infective endocarditis, septicemia, urinary and skin infections (Aguado-Urda et al. 2011), giving rise to the status of an emerging zoonotic pathogen. Although L. garvieae is a well-known fish pathogen, human infections are usually related to a contact with raw fish. It has gained recognition as an emerging zoonotic opportunistic pathogen, with the ingestion of contaminated foodstuffs being a likely route 
of infection. Handling and of raw fish is reported as a source or risk factor in the majority of clinical cases (Gibello et al. 2016). High levels of antibiotic resistance and resistance genes in L. garvieae strains should be considered as a potential danger for trout culture as well as for public health (Raissy and Moumeni, 2016).

In this paper, we report the first case of lactococcosis in rainbow trout in Serbia, isolation and characterization of causative agent, L. garvieae from diseased rainbow trout (Oncorhynchus mykiss, Walbaum).

\section{MATERIAL AND METHODS}

A total of 20 rainbow trout (weighing 70-120g) that showed the clinical signs of the disease were collected from a trout aquaculture facility in CentralWest Serbia in July, 2018. The samples for bacterial isolation were obtained from the kidney, liver, spleen and eye of the diseased fish. They were streaked on blood agar plates containing 10\% defibrinated sheep blood (BA), MuellerHinton (MH) agar and trypticase-soy agar (TSA) plates, and incubated at $20^{\circ} \mathrm{C}$ for $48 \mathrm{~h}$. Single colonies were restreaked on the same media to obtain pure isolates. Pure colonies were subjected to Gram staining, followed by catalase and oxidase tests. The routine tests for the determination of biochemical characteristics were carried out as previously described (Austin \& Austin 2016). Additionally, the BBL CRYSTAL ${ }^{\mathrm{rm}}$ Gram-Positive (GP) Identification (ID) system was used for the biochemical identification of isolated bacterium.

The isolate was tested for antimicrobial susceptibility by the disc diffusion method on $\mathrm{MH}$ agar. After $24 \mathrm{~h}$ of the incubation, incubation zone diameters were measured and evaluated. The isolates were classified as sensitive (S), intermediary sensitive (I), or resistant (R), on the basis of the size of the zone of bacterial growth inhibition, according to the National Committee for Clinical Laboratory Standards (CLSI, 2019).

\section{MALDI-TOF}

Protein mass spectroscopy analysis was carried out by matrix-assisted laser desorption/ionization time-of-flight mass spectrometry (MALDI-TOF MS) as previously described (Heras Cañas et al. 2015) using a VITEK MS Mass spectrometry microbial identification system (VITEK MS, bioMerieux, France). 


\section{$16 S$ rRNA sequence analysis}

Total bacterial DNA of the isolate was extracted using the Cador Pathogen Mini Kit (Qiagen, Germany), following the manufacturer's instructions. The extracted DNA from the isolate was used as a template to amplify a 1419bp segment of the 16S rRNA gene by the polymerase chain reaction (PCR) technique using the universal prokaryotic primers 27F (5'-AGAGTTTGATCCTGGCTCAG-3') and 1492R (5' GGTTACCTTGTTACGACTT-3'). The composition of PCR mixture was as recommended by manufacturer (HotStarTaq Master Mix Kit, Qiagen, Germany). The PCR cycling regime was the following: one cycle of $15 \mathrm{~min}$ denaturation and Taq activation at $95^{\circ} \mathrm{C}, 35$ cycles of $40 \mathrm{~s}$ at $95^{\circ} \mathrm{C}, 40 \mathrm{~s}$ at $55^{\circ} \mathrm{C}$, and $90 \mathrm{~s}$ at $72^{\circ} \mathrm{C}$, and final extension cycle of $10 \mathrm{~min}$ at $72^{\circ} \mathrm{C}$. A small quantity of PCR products was verified by standard agarose gel electrophoresis. The amplicons were purified using QIAquick PCR Purification kit (Qiagen, Germany) and sequenced using the primers 27F and $1492 \mathrm{R}$. The sequencing of PCR product was performed by Macrogen. The isolate sequence was compared to sequences from the NCBI database, using the BLASTn algorithm. The limit fixed for identification of a bacterial species was $98 \%$ nucleotide identity for the $16 \mathrm{~S}$ rRNA gene. The phylogenetic relationships of the isolates were determined by comparative $16 \mathrm{~S}$ rRNA gene sequence analysis. Genetic distances matrix was obtained using Kimura's two-parameter model, and an evolutionary tree was created using the Neighbour-Joining method with Mega X (Kumar et al.2018).

\section{RESULTS}

The disease outbreak affecting rainbow trout weighing 70 - $120 \mathrm{~g}$ occurred at a trout aquaculture facility in Zaovine Lake (43⒌ $\left.46.3^{\prime \prime} \mathrm{N} 19^{\circ} 24^{\prime} 08.4^{\prime \prime} \mathrm{E}\right)$ during July, 2018. This outbreak lasted for three weeks, and cumulative mortality attributed to this pathogen was around $40 \%$. The water temperature during the outbreak was consistently higher than $14^{\circ} \mathrm{C}$ (with highest temperature of $20^{\circ} \mathrm{C}$ ). The infected fish exhibited lethargy, anorexia, dark skin coloration, marked unilateral and bilateral exophthalmos with the presence of generalized hemorrhaging or blood spots in the eye, eyeball disruption and loss of eye or eyes (Figure 1). 


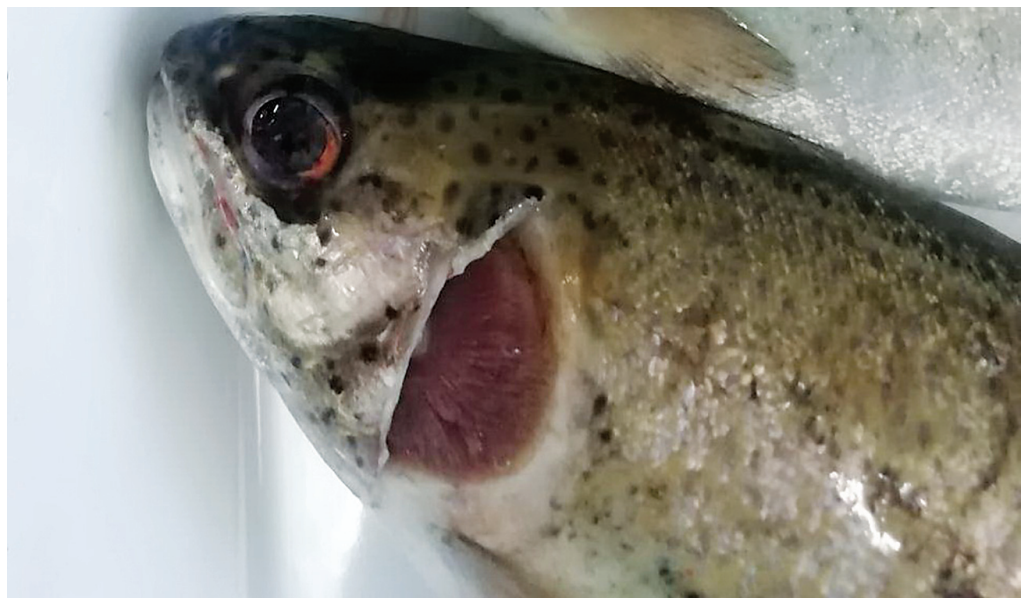

Figure 1. The hemorrhaging in the eye and exophthalmos in diseased rainbow trout caused by lactococcosis

Macroscopic examination revealed the accumulation of fluid in the body cavity. Skeletal muscle and liver were anemic with congestion. Liver and spleen were enlarged. Hemorrhages were present in liver, adipose tissue, pyloric caeca and muscle. Enlargement of the spleen and liver, and hemorrhagic enteritis with yellow, gelatinous fluid in the lumen of intestine were observed (Figure 2).

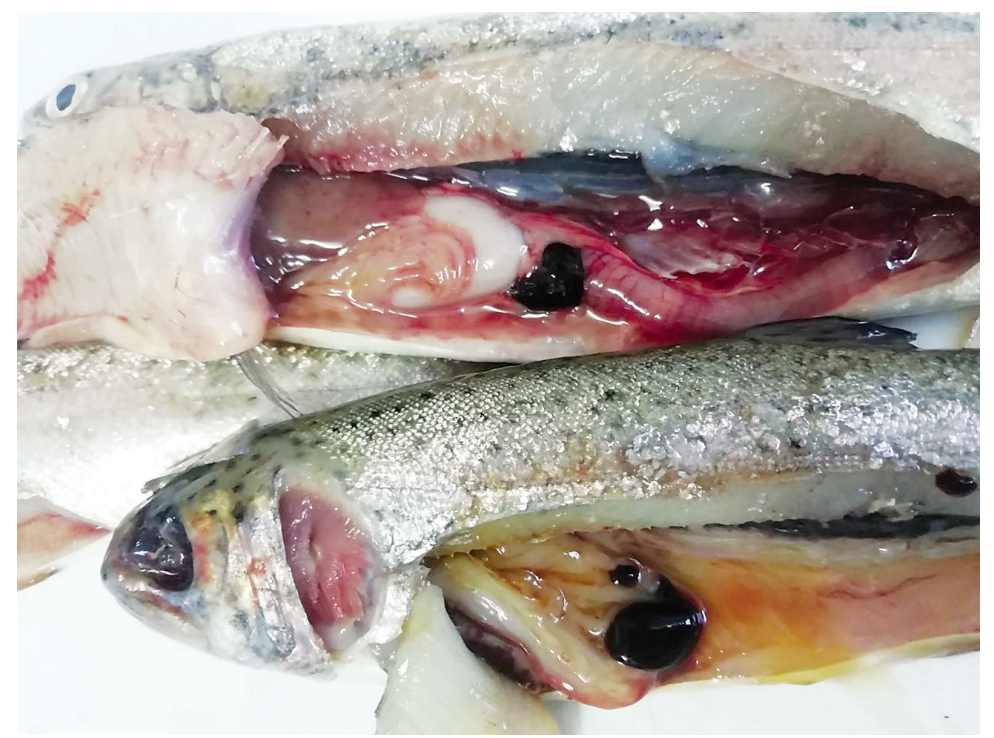

Figure 2. Lactococcosis in rainbow trout - hemorrhages in internal organs, enlargement of the spleen and liver, and yellow, gelatinous fluid in the lumen of intestine 
After $48 \mathrm{~h}$ incubation, pure cultures of cream-colored, opaque, round and convex colonies were recovered from eye and kidney samples (Figure 3 ).

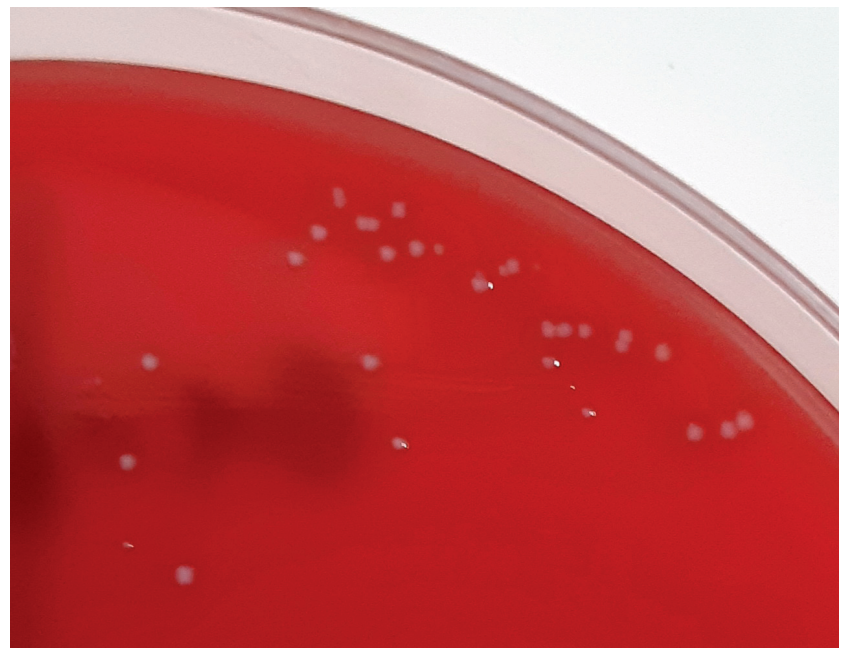

Figure 3. Growth of colonies of L. garvieae SRB NIVS-1 strain on a blood agar plate after 24 hours of incubation in aerobic conditions.

The bacterial cells were $\alpha$-hemolytic, non-motile, oxidase-negative, catalasenegative, Gram-positive cocci occurring in pairs and short chains (Figure 4).

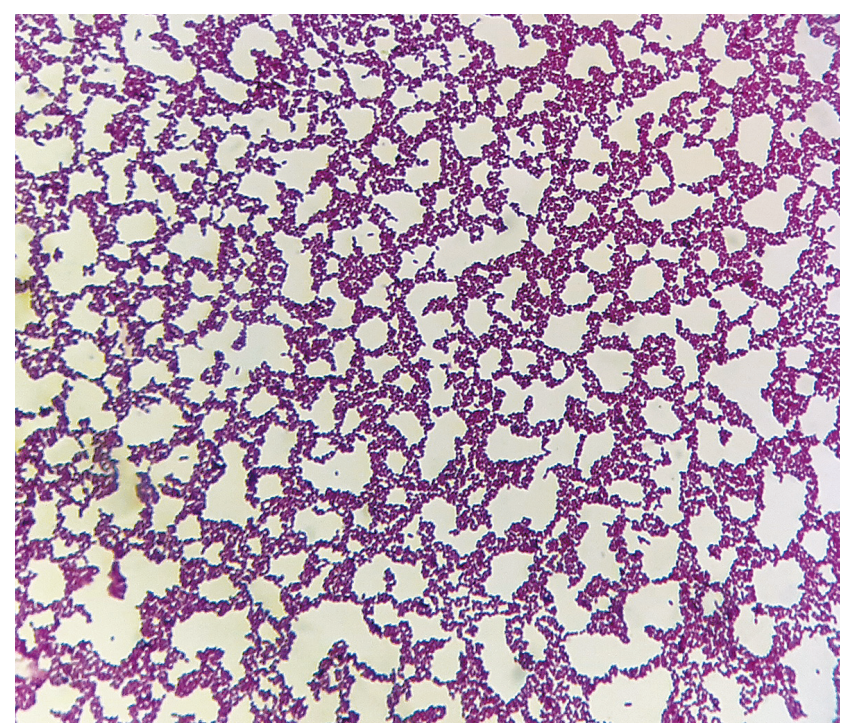

Figure 4. Gram stain of L. garvieae SRB NIVS-1 strain with clusters and short chains of gram-positive cocci. 
Based on colony morphology, phenotypic and biochemical characteristics, the isolated bacterium was presumably identified as L. garvieae (Table 1).

Table 1. Phenotypic characteristic of L. garvieae SRB NIVS-1 strain isolated from diseased rainbow trout.

\begin{tabular}{lcc}
\hline \multicolumn{1}{c}{ Phenotypic characteristics } & $\begin{array}{c}\text { L. garvieae } \\
\text { SRB NIVS-1 }\end{array}$ & $\begin{array}{c}\text { L. garvieae } \\
\text { ATCC 43921 }\end{array}$ \\
\hline Colony morphology & smooth & smooth \\
\hline Cell morphology & ovoid-cocci & ovoid-cocci \\
\hline Gram staining & + & + \\
\hline Motility & - & - \\
\hline Production of oxidase & - & - \\
\hline Production of catalase & - & - \\
\hline Production of indole & - & - \\
\hline Production of H,S & - & - \\
\hline Citrate utilization & - & - \\
\hline Methyl red & + & + \\
\hline Voges Proskauer & + & + \\
\hline Nitrate reduction & - & - \\
\hline Starch hydrolysis & - & - \\
\hline Growth on nutrient agar & + & + \\
\hline Growth on trypticase soy agar & + & + \\
\hline Growth on brain heart infusion agar & + & - \\
\hline Growth on Mueller-Hinton agar & + & $\alpha$ \\
\hline Growth on MacConkey agar & - & + \\
\hline Hemolysis in blood agar & $\alpha$ & \\
\hline
\end{tabular}

Using the BBL CRYSTAL GP ID system, the isolate was identified as $L$. garvieae ID: 3440571723 (Table 2).

Table 2. The BBL Crystal profile for L. garvieae isolated from diseased rainbow trout

\begin{tabular}{lclc}
\hline L-phenylalanine-AMC & + & p-nitrophenyl- $\beta$-D-cellobioside & + \\
\hline L-tryptophan-AMC & + & p-nitrophenyl- $\alpha$-D-maltoside & + \\
\hline Trehalose & + & Esculin & + \\
\hline Sucrose & + & L-valine-AMC & +- \\
\hline Arabinose & - & pyroglutamic acid-AMC & +- \\
\hline
\end{tabular}




\begin{tabular}{lclc}
\hline $\begin{array}{l}\text { p-nitrophenyl- } \beta- \\
\text { D-glucoside }\end{array}$ & + & 4MU-N-acetyl- $\beta$-D-glucosaminide & +- \\
\hline $\begin{array}{l}\text { p-nitrophenyl- } \\
\text { phosphate }\end{array}$ & - & L-isoleucine-AMC & + \\
\hline Urea & - & Methyl- $\alpha$ \& $\beta$-glucoside & + \\
\hline 4MU- $\beta$-D-glucoside & + & Maltotriose & + \\
\hline 4MU- $\alpha$-D-glucoside & + & Fructose & + \\
\hline L-arginine-AMC & +- & Proline \& Leucine-p-nitroanilide & + \\
\hline & & o-nitrophenyl- $\beta$-D-galactoside & \\
Lactose & - & (ONPG) \& p-nitrophenyl- & - \\
\hline Mannitol & & $\alpha-D-$ galactoside & \\
\hline Glycerol & + & ID: 3440571723 Lactococcus garvieae & \\
\hline
\end{tabular}

The L. garvieae isolate was tested in the present study with 15 different antimicrobials in terms of antimicrobial sensitivity and results are shown in Table 3.

Table 3. Antibiotic sensitivity of L. garvieae isolate SRB NIVS-1 isolated from diseased rainbow trout

\begin{tabular}{ll}
\hline \multicolumn{1}{c}{ Antibiotic } & Sensitivity \\
\hline Flumequine $(15 \mu \mathrm{g})$ & $\mathrm{R}$ \\
\hline Oxytetracycline $(30 \mu \mathrm{g})$ & $\mathrm{S}$ \\
\hline Sulfamethoxazole/trimethoprim $(25 \mu \mathrm{g})$ & $\mathrm{R}$ \\
\hline Enrofloxacin $(5 \mu \mathrm{g})$ & $\mathrm{R}$ \\
\hline Florfenicol $(30 \mu \mathrm{g})$ & $\mathrm{S}$ \\
\hline Penicillin $\mathrm{G}(10 \mathrm{IU})$ & $\mathrm{S}$ \\
\hline Ampicillin $(10 \mu \mathrm{g})$ & $\mathrm{S}$ \\
\hline Amoxycillin $(25 \mu \mathrm{g})$ & $\mathrm{S}$ \\
\hline Tetracycline $(30 \mu \mathrm{g})$ & $\mathrm{S}$ \\
\hline Gentamycin $(10 \mu \mathrm{g})$ & $\mathrm{R}$ \\
\hline Neomycin $(10 \mu \mathrm{g})$ & $\mathrm{R}$ \\
\hline Streptomycin $(10 \mu \mathrm{g})$ & $\mathrm{R}$ \\
\hline Trimethoprim $(5 \mu \mathrm{g})$ & $\mathrm{R}$ \\
\hline Erythromycin $(15 \mu \mathrm{g})$ & $\mathrm{S}$ \\
\hline Oxacillin $(1 \mu \mathrm{g})$ & $\mathrm{R}$ \\
\hline
\end{tabular}

To further confirm our result, the L. garvieae strain SRB NIVS-1 was identified with MALDI-TOF, which also confirmed the identity of our isolate. To 
determine the genotype identity, we have extracted and sequenced the $16 \mathrm{~S}$ rRNA (1419 bp, NCBI Genbank accession number MT000099) of strain SRB NIVS- 1 and blasted using BLAST search program in the GenBank of NCBI, which revealed $99.6 \%$ sequence identity with $L$. garvieae. The sequence was compared with the sequences of reference species in Genebank data library by the BLAST program. Blast analysis of $16 \mathrm{~S}$ rRNA sequence of our isolate presented a 99.4 to $99.6 \%$ similarity in sequences to the L. garvieae strains previously isolated from diseased fish. The isolate showed high percentage sequence similarity to other strains of L. garvieae: $99.6 \%$ sequence similarity to MG016446 from China, 99.5 \% sequence similarity to KT428591 from Turkey and $99.4 \%$ sequence similarity to KU360715 from Iran. The relationship between the strain SRB NIVS-1 and the closest taxonomic species based on $16 \mathrm{~S}$ rDNA sequences is described in the phylogenetic tree (Figure 5).

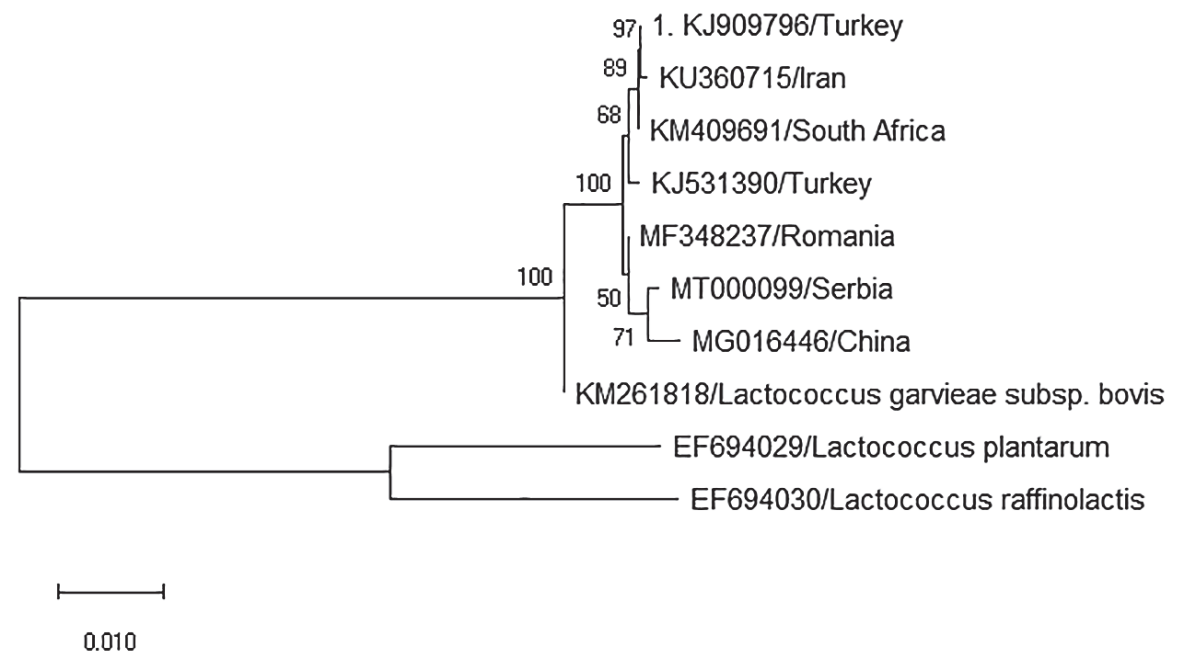

Figure 5. Phylogenetic tree based on $16 \mathrm{~S}$ rRNA gene sequences showing the position of L. garvieae SRB NIVS-1 strain

The evolutionary history was inferred using the Neighbor-Joining method. The optimal tree with the sum of branch length $=0.15577609$ is shown. The percentage of replicate trees in which the associated taxa clustered together in the bootstrap test (1,000 replicates) is shown next to the branches. The tree is drawn to scale, with branch lengths in the same units as those of the evolutionary distances used to infer the phylogenetic tree. 


\section{DISCUSSION}

The outbreak of the lactococcosis affecting rainbow trout occurred at a trout aquaculture facility in Zaovine Lake, an artificial lake in the CentralWest Serbia, on the Tara Mountain, created on the Beli Rzav River as a reservoir for the Bajina Bašta II reversible hydro power plant. This outbreak with a total mortality of around $40 \%$ lasted for three weeks. Rainbow trout mortality due to L. garvieae infection can be up to $60 \%$, depending on the water temperature, stress for fish and strain type of the bacterium (Shahi et al, 2018). The water temperature during the outbreak was consistently higher than $14^{\circ} \mathrm{C}$ (with highest temperature of $20^{\circ} \mathrm{C}$ ). Such high temperature was a critical environmental condition for the appearance of the disease with a high mortality (Pereira et al., 2004, Castro et al. 2017). Clinical findings during the course of the disease, including characteristic symptoms as hyperpigmentation and bilateral exophthalmia, were similar to those previously described in other studies (Evans et al. 2009, Algöet et al.2009, Austin and Austin, 2016).

Pure colonies of the gram positive streptococcus, non-motile, negative for oxidase and catalase, with properties typical for the Lactococcus garvieae, as previously described by Collins et al. (1983), were recovered from eye and kidney samples from the diseased rainbow trout. L. garvieae strains are phenotypically homogeneous, regardless of their geographic location or the aquatic host from which they were isolated (Buller, 2014). The biochemical properties of the isolated bacteria from rainbow trout were analogous to those described by Austin \& Austin (2016). The taxonomy based on a molecular level was used to establish the phylogenesis and taxonomic position of the bacterium. Preferred methods for the identification of L. garvieae are MALDI-TOF MS and 16s rRNA gene PCR (Heras Cañas et al. (2015). It is important to emphasize that this pathogen causes serious economic losses due to increased mortality rates (up to 50\%), decreasing the growth rates. The appearance of sick fish makes them unmarketable (Vendrell et al 2006). L. garvieae is a major fish pathogen of rainbow trout in Europe. To our knowledge, this is the first report of L. garvieae associated with trout diseases in Serbia. However, it is likely that the lactococcosis in rainbow trout will become more frequent in the future.

\section{CONCLUSION}

This study confirmed that L. garvieae was the etiological agent of a hemorrhagic septicemia in farmed rainbow trout and that the lactococcosis of rainbow trout caused by L. garvieae emerged in Serbia. The occurrence could 
be attributed to the significant increase in water temperature during summer months, since water temperature is described as the most important environmental factor in the development of the L. garvieae infections in trout. In addition, variations in water temperature can affect fish immune response against bacterial infection. Lactococcosis is a limiting problem for rainbow trout culture in many South European countries. After the first occurrence in Spain and Italy, the pathogen and the associated disease has spread rapidly throughout the South Europe, and further to the South-Eastern part of the continent, with disease outbreaks in Greece, Bulgaria and Turkey. In the affected countries, lactococcosis is a major threat to trout culture, especially during awarm period. The rapid spread of the pathogen is a result of the multiple routes of dissemination and transmission of this pathogen. This includes direct spread though the movement of infected fish or asymptomatic carriers and transmission via contaminated water (Savvidis et al., 2007). Since L. garvieae have the ability to adapt and survive in many environmental conditions including a wide range of $\mathrm{pH}$, temperatures, salinity concentrations and nutrient sources (Kusuda et al. 1991), the occurrence of the disease in Serbia is a warning for the neighboring countries with trout aquaculture. It is evident that this agent spreads to the new geographic areas, causing the disease with high mortality in susceptible population. The source of outbreak is not known, but since the disease is present in the region and susceptible species are in a river basin which is shared between countries, under adequate conditions, further spread of the causative agent and concomitant disease is inevitable. Due to the ability of L. garvieae to colonize multiple, diverse environments, and because it causes infection in a broad range of different hosts, it is reasonable to expect further spread of the bacterium and the disease. Since vaccination is considered the best option to control lactococcosis in rainbow trout, we hope that an appropriate strategy to prevent this infection on Serbian trout farms will be available in the future.

\section{ACKNOWLEDGEMENT}

This study was financially supported by a grant from the Ministry of Education, Science and Technology Development of the Republic of Serbia.

\section{Author's contributions:}

VR, OR, NZ and MS made contributions to concept and design of the study, they collected data and drafted the manuscript. JMZ and BS carried out the molecular diagnostic tests and prepared the alignment of nucleotide 
sequences and conducted the molecular genetic analysis. LJV carried out the data analysis. KN revised the manuscript critically and together with VR prepared the final draft of the manuscript. All the authors read and approved the final manuscript.

\section{Competing Interests}

The authors declare that they have no competing interests.

\section{REFERENCES}

1. Aguado-Urda M., Gibello A., Blanco M.M., Garayzábal J.F., López-Alonso V., López-Campos G.H. 2013. Global Transcriptome Analysis of Lactococcus garvieae Strains in Response to Temperature. PLoS One, 8(11): e79692. doi: 10.1371/journal.pone.0079692.

2. Aguado-Urda M., López-Campos G.H., Gibello A., Cutuli M.T., LópezAlonso V., Fernández-Garayzábal J.F., Blanco M.M. 2011. Genome sequence of Lactococcus garvieae 8831, isolated from rainbow trout lactococcosis outbreaks in Spain. Journal of bacteriology, 193: 4263-4264. doi: 10.1128/JB.05326-11.

3. Algöet M., Bayley A.E., Roberts E.G., Feist S.W., Wheeler R.W., VernerJeffreys D.W. 2009. Susceptibility of selected freshwater fish species to a UK Lactococcus garvieae isolate. Journal of Fish Diseases, Oct .32(10):825-34. doi: 10.1111/j.1365-2761.2009.01058.x.

4. Austin B. and Austin A.D. 2016. Bacterial fish pathogens: Diseases of farmed and wild fish, Springer International Publishing, 6th edition, ISBN 978-3-319-32674-0.

5. Avci H., Aydoğan A., Tanrikul T.T., Birincioğlu S.S. 2010. Pathological and microbiological investigations in rainbow trout (Oncorhynchus mykiss Walbaum, 1792) naturally infected with Lactococcus garvieae. Kafkas Univ Vet Fak Derg 16 (Suppl-B): S313-S318, 2010 DOI:10.9775/kvfd.2010.2452

6. Buller N. 2014. Bacteria and Fungi from fish and other aquatic animals, Bentley, Western Australia: CABI Publishing, 2nd Ed, ISBN 9781845938055. doi: 10.1079/9781845938055.0000.

7. Castro R., Eguera-Brito M.R., López-Campos G.H., Blanco M.M., Aguado-Urda M., Fernández-Garayzábal J.F., Gibello A. 2017. How does temperature influences the development of lactococcosis? Transcriptomic and immunoproteomic in vitro approaches. Journal of Fish Diseases, 40, 10, 1285-1297. doi: 10.1111/jfd.12601. 
8. Ceschia G., Giorgetti E., Mazzolini E., Danielis L., Passera A. 1998. Vaccination against streptococcosis in farmed rainbow trout (Oncorhynchus mykiss). Journal of Applied Ichthyology, 14:185-187.

9. CLSI. 2019. Performance Standards for Antimicrobial Susceptibility Testing. 29th ed. CLSI supplement M100. Wayne, PA: Clinical and Laboratory Standards Institute.

10. Collins M.D., Farrow J.A., Phillips B.A., Kandler O. 1983. Streptococcus garvieae sp.nov. and Streptococcus plantarum sp. nov. Journal of General Microbiology, 129, 3427-3431. doi: 10.1099/00221287-129-11-3427.

11. Diler O., Altun S., Adiloglu A.K., Kubilay A., Isikli B. 2002. First occurrence of streptococcosis affecting farmed rainbow trout (Oncorhynchus mykiss) in Turkey. Bulletin- European Association of Fish Pathologists, 22:21-26.

12. Evans J.J., Klesius P.H., Shoemaker C.A. 2009. First isolation and characterization of Lactococcus garvieae from Brazilian Nile tilapia, Oreochromisniloticus (L.), and pintado, Pseudoplathy stomacorruscans (Spix \& Agassiz). Journal of Fish Diseases, 32, 943-951. doi:10.1111/j.13652761.2009.01075.x.

13. Eldar A. and Ghittino C. 1999. Lactococcus garvieae and Streptococcus iniae infections in rainbow trout (Oncorhynchus mykiss): two similar but different diseases. Diseases of Aquatic Organisms, 1999, 36, 227-231. doi: $10.3354 /$ dao036227.

14. Eyngor M., Zlotkin A., Ghittino C., Prearo M., Douet D.G., Chilmonczyk S., Eldar A. 2004. Clonality and diversity of the fish pathogen Lactococcus garvieae in Mediterranean countries. Applied and Environmental Microbiology, 70 (9): 5132-5137. doi: 10.1128/AEM.70.9.5132-5137.2004.

15. Fortina M.G., Ricci G., Foschino R., Picozzi C., Dolci P., Zeppa G., Cocolin L., Manachini P.L. 2007. Phenotypic typing, technological properties and safety aspects of Lactococcus garvieae strains from dairy environments. Journal of Applied Microbiology, 103, 445-453. doi: 10.1111/j.13652672.2006.03265.x.

16. Foschino R., Nucera D., Volponi G., Picozzi C., Ortoffi M., Bottero M.T. 2008. Comparison of Lactococcus garvieae strains isolated in northern Italy from dairy products and fishes through molecular typing. Journal of Applied Microbiology, 105, 652-662. doi: 10.1111/j.1365-2672.2008.03780.x.

17. Gibello A, Galán-Sánchez F, Blanco M.M., Rodríguez-Iglesias M, Domínguez L, Fernández-Garayzábal J.F. 2016. The zoonotic potential of Lactococcus garvieae: an overview on microbiology, epidemiology, virulence factors and relationship with its presence in foods. Research in Veterinary 
Science, 109: 59-70. doi: 10.1016/j.rvsc.2016.09.010.

18. Heras Cañas V., Pérez Ramirez M.D., Bermudez Jiménez F., Rojo Martin M.D., Miranda Casas C., Marin Arriaza M., Navarro Marí J.M. 2015. Lactococcus garvieae endocarditis in a native valve identified by MALDI-TOF MS and PCR-based 16s rRNA in Spain: A case report. New Microbes and New Infections, 5: 13-15. doi: 10.1016/j.nmni.2015.02.001 .

19. Kumar S., Stecher G., Li M., Knyaz C., Tamura K. 2018. MEGA X: Molecular Evolutionary Genetics Analysis across computing platforms. Molecular Biology and Evolution, 35:1547-1549. doi: 10.1093/molbev/msy096.

20. Kusuda R., Kawai K., Salati F., Banner C.R., Fryer J.L. 1991. Enterococcus seriolicida sp. nov., a fish pathogen. International journal of systematic bacteriology, 41(3):406-9. doi: 10.1099/00207713-41-3-406.

21. Meyburgh C.M., Bragg R.R., Boucher C.E. 2017. Lactococcus garvieae: an emerging bacterial pathogen of fish. Diseases of Aquatic Organisms, 123(1):67-79. doi: 10.3354/dao03083.

22. Nakai T., Sugimoto R., Park K.H., Matsuoka S., Mori K, Nishioka T., Maruyama K. 1999. Protective effects of bacteriophage on experimental Lactococcus garvieae infection in yellowtail. Diseases of Aquatic Organisms, 37, 33-41. doi: 10.3354/dao037033.

23. Palacios M.A., Zamora M.J., Vazquez J, Zamora E, Duran A. 1993. Streptococcosis in rainbow trout (Oncorhynchus mykiss) in Spain. Boll Soc It Patol Ittica, 13, 11-16.??? (časopis)

24. Pereira F., Ravelo C., Toranzo A., Romalde J. 2004. Lactococcus garvieae, an emerging pathogen for the Portuguese trout culture. Bulletin of the European Association of Fish Pathologists, 24, 274-279.

25. Raissy M. and Moumeni M. 2016. Detection of antibiotic resistance genes in some Lactococcus garvieae strains isolated from infected rainbow trout. Iranian Journal of Fisheries Sciences, 15 (1): 221-229.

26. Reimundo P., Pignatelli M., Alcaraz L.D., D’Auria G., Moya A., Guijarro J.A. 2011. Genome sequence of Lactococcus garvieae UNIUD074, isolated in Italy from a lactococcosis outbreak. Journal of bacteriology, 193: 3684-3685. doi: 10.1128/JB.05210-11.

27. Savvidis G.K., Anatoliotis C., Kanaki Z., Vafeas G. 2007. Epizootic outbreaks of Lactococcosis disease in rainbow trout, Oncorhynchus mykiss (Walbaum), culture in Greece. Bulletin- European Association of Fish Pathologists, 27: 223-228.

28. Shahi N., Mallik S.K, Sahoo M., Chandra S., Singh A.K. 2018. First report on characterization and pathogenicity study of emerging Lactococcus garvieae infection in farmed rainbow trout, Oncorhynchus mykiss (Wal- 
baum), from India. Transboundary and Emerging Diseases, 65 (4): 10391048 doi: $10.1111 /$ tbed.12843.

29. Tejedor J.L., Vela A.I., Gibello A., Casamayor A., Domínguez L., Garayzábal J.F. 2011. A genetic comparison of pig, cow and trout isolates of Lactococcus garvieae by PFGE analysis. Letters in Applied Microbiology, 53, 6, (614-619). doi: 10.1111/j.1472-765X.2011.03153.x.

30. Vendrell D., Balcázar J.L., Ruiz-Zarzuela I., de Blas I., Gironés O., Múzquiz J.L. 2006. Lactococcus garvieae in fish: a review. Comparative Immunology Microbiology and Infectious Diseases, 29:177-198. doi: 10.1016/j. cimid.2006.06.003.

Received: 01.04.2020.

Accepted: 19.06.2020. 